\title{
Gender preference on the quality of landscape aesthetic of urban agriculture
}

\author{
Diah Retno Dwi Hastuti*, Rahim Darma², Darmawan Salman², Slamet Santosa², Triyatni \\ Martosenjoyo ${ }^{2}$, and Novaty Eny Dungga ${ }^{2}$ \\ 1 Universitas Negeri Makassar, Makassar, Indonesia \\ 2Universitas Hasanuddin, Makassar, Indonesia \\ *Correspondence email: diah.retno@unm.ac.id
}

\section{ARTICLE INFO}

\section{- Research Article}

Article History

Received 2 February 2021

Accepted 1 March 2021

Published 1 April 2021

\section{Keywords}

COVID-19; gender preference; Scenic Beauty

Estimation; urban

agriculture; urban landscape

JEL Classification

C00; O13; Q19

\begin{abstract}
In addition to providing food benefits, urban agriculture also has aesthetic benefits. Therefore, a visual assessment of the urban agricultural landscape can be used to measure this aesthetic value. Gender preference is also carried out to see differences in visual assessment. This research was conducted in Makassar City using primary data with 129 respondents consisting of 53 people who had never been to Makassar and 76 people who had been/lived in Makassar. The aesthetic assessment of agricultural landscapes in Makassar City used the Scenic Beauty Estimation (SBE) method with a perceptual dimension. The results showed that the most beautiful urban agricultural landscapes had a high level of preference, namely in various plant gardens and verticultural hydroponic systems. Furthermore, the highest SBE score as a potential attraction was shown by male respondent who had never been to Makassar. Possible urban agricultural landscape resources should receive special attention by arranging them neatly and cleanly so that they have high artistic value to provide beauty and comfort for visitors.
\end{abstract}

To cite this article: Hastuti, D. R. W., Darma, R., Salman, D., Santosa, S., Martosenjoyo, T., \& Dungga, N. E. (2021). Gender preference on the quality of landscape aesthetic of urban agriculture. Journal of Socioeconomics and Development, 4(1), 57-68. https://doi.org/10.31328/jsed.v4i1.2164

ISSN 2615-6075 online; ISSN 2615-6946 print (C)WG Press, 2021

\section{INTRODUCTION}

A person's preferences and satisfaction with aesthetics are very complicated and have high diversity (Palmer et al., 2013; Redies, 2014) because of culture (Bonsdorff, 2005; Frank et al., 2013; Jacobsen, 2010), human activities with their environment (Brady, 2006; Hidayat, 2009; Hill \& Daniel, 2007), and aspects of well-being (Hedblom et al., 2020). Daniel \& Boster (1976) revealed that aesthetic judgments are partly determined by environmental characteristics and depend on human judgment which sometimes has a halo effect (Hartmann et al., 2008). Therefore, a method for calculating the value of a landscape's beauty based on perceptions and preferences is represented by evaluative judgments and perceptions of the scenic beauty of a landscape. The higher the assessment, the higher the aesthetic value (Child, 1964; Daniel \& Boster, 1976; Frank et al., 2013).

Assessment of the quality of landscape beauty includes two approaches. They are the one based on experts and perceptions (Sowińska-Świerkosz \& Chmielewski, 2016) and the one based on the interaction between the biophysical features of the landscape and human process perception/experience (Daniel, 2001; Peng \& Han, 2018). Such evaluation 
results from subjective assessment (Lothian, 1999), which considers certain landscape elements and the characteristics of stimuli causing relevant psychological responses in the form of sensory perceptions and perceptions that arise from cognition (Peng \& Han, 2018). Perception of this landscape is strongly influenced by the characteristics of the landscape as a whole (Molnárová et al., 2017; Svobodova et al., 2014) as well as the sociodemographic characteristics (Dearden, 1984; LópezMartínez, 2017; Skřivanová et al., 2014). Expert-based approaches are more efficient in terms of cost and time than perception-based ones. However, it is more comfortable to verify the reliability and validity of the perception-based approach than those of the expertbased approach when using statistical methods (Molnárová et al., 2017; Peng \& Han, 2018).

Changes in socioeconomic conditions, such as increased income and leisure time (Li et al., 2020a) and pandemics (Chenarides et al., 2021; Geng et al., 2020; Khan et al., 2020; Xie et al., 2020), have increased the number of visitors to green open spaces such as parks and urban agriculture as a form of recreation to reduce stress (Khan et al., 2020). It means that the aim of meeting urban food needs to lead to sustainable agriculture. Therefore, it is necessary to evaluate the existence of green open space landscape, especially urban agriculture. The estimation method of SBE is deemed sufficient (Mo et al., 2021). It is widely used to evaluate landscape quality with a more valid and reliable psychophysical approach (Peng \& Han, 2018) when compared to subjective evaluation (Li et al., 2020a). Thus, aesthetic evaluation using the SBE method can estimate more objectively the aesthetic value of a landscape.

Research on the beauty preference of various research objects with the application of SBE has been widely carried out in various countries as a driving factor for visual landscape preferences in the Czechosklavian landscape area (Skřivanová et al., 2014). Likewise, the aesthetic quality assessment is conducted to soil and water (Peng \& Han, 2018) and city parks (Shi et al., 2020) in Taiwan, as well as the beauty of tree colours (Wang et al., 2020) and urban park landscapes (Li et al., 2020a) during autumn in China. It has also been researched in Indonesia, such as on coastal tourism area landscape planning (Budiyono et al., 2013) and cultural-based landscape evaluation (Nurfaida et al., 2019). However, research on the assessment of gender preference on the aesthetic quality of urban agricultural landscapes using the SBE method has not been conducted.

\section{RESEARCH METHOD}

This study involved 129 respondents consisting of 53 people who had never been to Makassar (16 men and 37 women) and 76 people who had been/lived in Makassar (46 men and 30 women). All respondents filled out questionnaires online through the Google Form application due to the COVID-19 pandemic, and this was done randomly. Overall, respondents rated twenty landscapes depicting the agricultural state of Makassar City.

The aesthetic assessment of the agricultural landscape of Makassar City used the Scenic Beauty Estimation (SBE) method with perceptual dimensions. This method features several agricultural landscapes of Makassar City, which are given a rating of between 1 and 10 where the score of 1 is for the most disliked landscape and the score of 10 is for the most favored landscape. This assessment was used to estimate aesthetic value by first converting it to a standard $\mathrm{z}$ score (Daniel \& Boster, 1976) as follows.

$$
z_{i j}=\frac{R_{i j}-\bar{R}_{i j}}{s_{j}}
$$

where $z_{i j}$ is the standard $z$-value for the $i^{\text {th }}$ assessment of the $j^{\text {th }}$ observation, $R_{i j}$ is the $i^{\text {th }}$ value of the $j^{\text {th }}$ observation, $\bar{R}_{i j}$ is the average of all $\mathrm{j}^{\text {th }}$ observational assessments, and $s_{j}$ is standard deviation of all $j^{\text {th }}$ observations.

Furthermore, the $z$ value is used to determine the SBE value with the equation:

$$
S B E_{x}=\left(z_{y x}-z_{y 0}\right) \times 100
$$

where $S B E_{x}$ is estimation of the $x^{\text {th }}$ agricultural aesthetics, $z_{y x}$ is $z$-average value of the $x^{\text {th }}$ agricultural landscape, and $z_{y 0}$ is the average $z$ value of a standard agricultural landscape approaching 0 (zero). The SBE value obtained will be used to classify aesthetics into three categories: low, medium, and high aesthetics.

To determine the difference in visual perception of the two gender groups, we used the t-test as follows.

$$
t \text {-count }=\frac{\overline{x_{m}}-\overline{x_{f}}}{s \sqrt{\frac{1}{n_{m}}}-\frac{1}{n_{f}}}
$$

then $\overline{x_{m}}$ is the average SBE value of male respondents, $\overline{x_{f}}$ is the average SBE value of female respondents, $s$ 
is pool standard deviation, $n_{m}$ is number of male samples, and $n_{f}$ is number of female samples. The hypothesis testing was stated by measuring t-count.

The $\mathrm{t}$-count value obtained was then compared with the t-table value. If the value of $t$-count is greater than the value of the t-table, the alternative hypothesis will be accepted. It means that there are differences in the assessment of visual perceptions between men and women, and vice versa.

\section{RESULT AND DISCUSSION}

\section{Respondent Characteristics}

Table 1 shows that there are $48.83 \%$ of respondents aged $41-50$ years. The number of both male and female respondents in this age group is the largest compared to that in other age groups. The age group less than or equal to 20 years is the smallest number of respondents in each respondent group. The average age of the respondents was 38 years, ten months, and 20 days. Meawhile, the average male respondents were younger than female respondents, namely 38 years seven months 28 days compared to 39 years and one month and six days.

Table 1. Characteristic of Respondents

\begin{tabular}{|c|c|c|c|}
\hline Variable & Male & Female & Total \\
\hline & $\ldots \ldots \ldots$ & people & \\
\hline \multicolumn{4}{|l|}{ Age } \\
\hline$\leq 20$ years & 2 & 1 & 3 \\
\hline $21-30$ years & 14 & 17 & 31 \\
\hline $31-40$ years & 15 & 6 & 21 \\
\hline $41-50$ years & 27 & 36 & 63 \\
\hline$\geq 51$ years & 4 & 8 & 12 \\
\hline Average (years) & 38.7 & 39.1 & 38.9 \\
\hline \multicolumn{4}{|l|}{ Education level } \\
\hline Senior high school & 4 & 10 & 14 \\
\hline Associate Degree & 1 & 0 & 1 \\
\hline Bachelor & 15 & 28 & 43 \\
\hline Master & 28 & 23 & 51 \\
\hline Doctoral & 13 & 7 & 20 \\
\hline \multicolumn{4}{|l|}{ Kind of education } \\
\hline $\begin{array}{l}\text { Mathematics and natural science } \\
\text { education }\end{array}$ & 1 & 7 & 8 \\
\hline Engineering and planning & 5 & 2 & 7 \\
\hline Social and economic sciences & 31 & 21 & 52 \\
\hline Agriculture & 8 & 32 & 40 \\
\hline Health Sciences & 3 & 2 & 5 \\
\hline Others & 13 & 4 & 17 \\
\hline \multicolumn{4}{|l|}{ Profession } \\
\hline State Civil Apparatus & 7 & 5 & 12 \\
\hline Educator & 34 & 27 & 61 \\
\hline Employees of state public & 1 & 8 & 9 \\
\hline General employees & 2 & 6 & 8 \\
\hline Entrepreneur & 6 & 1 & 7 \\
\hline Others & 11 & 21 & 32 \\
\hline
\end{tabular}

The respondents' highest formal education level is at the masters' degree, amounting to $39.53 \%$. This value is supported by the male respondent group of $21.70 \%$. Meanwhile, only $10.85 \%$ of respondents did not receive higher education.

Furthermore, based on the type of education pursued by the most respondents in the agricultural sector and female respondents contributed $25.58 \%$. It is different from male respondents who mostly had a background in social and economic science education. Meanwhile, only one male respondent with a background in Mathematics and Natural Sciences Education and one female respondent in Engineering and Planning.

Respondents' occupations varied, where the work as an educator, both as teacher and lecturer, formed the largest number, namely 34 male respondents and 27 female respondents. In comparison, the smallest number of respondents' employment was as entrepreneurs in agriculture and design. Other occupations consisted of homemakers, researchers, and students.

\section{Visual Perception on Urban Agriculture}

Visual perception was given to the twenty agricultural landscapes of Makassar City, spread over several locations (Table 2).

The landscapes used to assess visual perception were spread in over five districts. Nine landscapes were owned individually, namely landscapes 1, 2, 3, $13,14,15,17,18$, and 20 . The rest were managed collectively by groups of women farmers and the gardening community. Those landscapes consisted of two food crop landscapes (landscapes 1 and 2), three ornamental plant landscapes (landscapes 13, 17, and 18 ), and 15 vegetable landscapes. There were six landscapes managed by men (landscapes 1, 2, 3, 13, 14 , and 19) and 14 landscapes managed by women, both individually and in communities.

The agricultural landscape of Makassar City had potential attractiveness to be developed based on the SBE results (Figure 1). The visual perception seen from the highest SBE score was in the 9th landscape and was given by male respondents who had never been to Makassar. Furthermore, the agricultural landscape in the 15th landscape was chosen by the man who had been/lived in Makassar. The agricultural landscapes in the 19th landscape was chosen by women who had been/lived in Makassar and the 8th landscape was by female respondents who had never 
been to Makassar. Meanwhile, the lowest SBE value or zero SBE is shown to be in the second landscape, given by the three respondents, except for the female respondents who had been/lived in Makassar.

Table 2. Description of Agricultural Landscapes in Makassar City

\begin{tabular}{|c|c|c|c|}
\hline No & Lanscape type & Description & Area \\
\hline 1 & Paddy field & Paddy fields of farmers in the Suka Maju's farmer group. & Manggala \\
\hline 2 & Cassava field & Individual cassava fields behind the sports stadium. & Biringkanaya \\
\hline 3 & Chili field & $\begin{array}{l}\text { Rainfed paddy fields are planted with chilies after the paddy growing season } \\
\text { and managed by farm laborers. }\end{array}$ & Tamalate \\
\hline 4 & Vegetable garden & A vegetable garden managed by Az-Zahra's women farmer group on idle land. & Tamalanrea \\
\hline 5 & Vegetable garden & A vegetable garden managed by Az-Zahra's women farmer group on idle land. & Tamalanrea \\
\hline 6 & Vegetable garden & $\begin{array}{l}\text { A vegetable garden managed by Citra's women farmer group on a vacant lot } \\
\text { by the Tallo River. }\end{array}$ & Panakkukang \\
\hline 7 & Vegetable garden & $\begin{array}{l}\text { A vegetable garden managed by Citra's women farmer group on a vacant lot } \\
\text { by the Tallo River. }\end{array}$ & Panakkukang \\
\hline 8 & Vegetable garden & $\begin{array}{l}\text { A vegetable garden managed by Dewi Sari's women farmer group on unused } \\
\text { residential land. }\end{array}$ & Tamalanrea \\
\hline 9 & Vegetable garden & $\begin{array}{l}\text { A vegetable garden managed by Dewi Sari's women farmer group on unused } \\
\text { residential land. }\end{array}$ & Tamalanrea \\
\hline 10 & Vegetable garden & $\begin{array}{l}\text { A vegetable garden managed by Melati's women farmer group on unused } \\
\text { land. }\end{array}$ & Manggala \\
\hline 11 & Vegetable garden & A vegetable garden managed by Nasa's women farmer group on unused land. & Biringkanaya \\
\hline 12 & Vegetable garden & $\begin{array}{l}\text { A vegetable garden managed by Selasih's women farmer group on unused } \\
\text { residential land. }\end{array}$ & Manggala \\
\hline 13 & Ornamental plant land & Ornamental plant land on vacant land beside the Jene'berang River & Tamalate \\
\hline 14 & Vegetable garden & a vegetable garden on a vacant lot beside the Jene'berang River & Tamalate \\
\hline 15 & Vegetables in the alley & $\begin{array}{l}\text { Vegetables along the alley use barrels and used planks on member of the } \\
\text { Dewi Sari's women farmer group. }\end{array}$ & Tamalanrea \\
\hline 16 & Chili in the alley & $\begin{array}{l}\text { Chili plants use polybags in the alley managed by Selasih's women farmer } \\
\text { group. }\end{array}$ & Manggala \\
\hline 17 & Ornamental plant & $\begin{array}{l}\text { Ornamental plants along the alleyways managed by member of the Perintis's } \\
\text { women farmer group. }\end{array}$ & Tamalanrea \\
\hline 18 & Ornamental plant & $\begin{array}{l}\text { Ornamental plants using pots and verticulture techniques in the yard on } \\
\text { member of the Asoka's women farmer group. }\end{array}$ & Tamalate \\
\hline 19 & Hidroponic verticulture & $\begin{array}{l}\text { Planting vegetables using hydroponic verticulture techniques in private } \\
\text { farming communities }\end{array}$ & Tamalate \\
\hline 20 & Aquaponic & $\begin{array}{l}\text { Planting vegetables using the aquaponics system on members of the Citra's } \\
\text { women farmer group. }\end{array}$ & Panakkukang \\
\hline
\end{tabular}

Table 3. Assessment of Gender Preference on The Aesthetic Quality of Makassar City Agriculture

\begin{tabular}{lcclc}
\hline Respondent group & Category & SBE score & Landscape \\
\hline & & & & Percentage \\
Male had never been to & low & $0-44.62$ & $2,3,16$ & 15 \\
Makassar (MnM) & middle & $44.63-89.25$ & $4,5,10,14,15$ & 25 \\
& high & $89.26-133.88$ & $1,6,7,8,9,11,12,13,17,18,19,20$ & 60 \\
\hline Male had been/ lived in & low & $0-44.49$ & $2,3,11,14$ & 20 \\
Makassar (MIM) & middle & $44.5-88.99$ & $1,4,5,9,20$ & 25 \\
& high & $89-133.49$ & $6,7,8,10,12,13,15,16,17,18,19$ \\
\hline Female had never been to & low & $0-34.44$ & $2,3,6,10$ & 55 \\
Makassar (FnM) & middle & $34.45-68.89$ & $4,5,9,11,14,18$ & 20 \\
& high & $68.90-103.34$ & $1,7,8,12,13,15,16,17,19,20$ \\
\hline Female had been / lived in & low & $0-38.18$ & 2,3 & \\
Makassar (FIM) & middle & $34.45-68.89$ & $4,6,8,13,14,15,17,18$ \\
& high & $76.38-114.56$ & $1,5,7,9,10,11,12,16,19,20$ \\
\hline
\end{tabular}




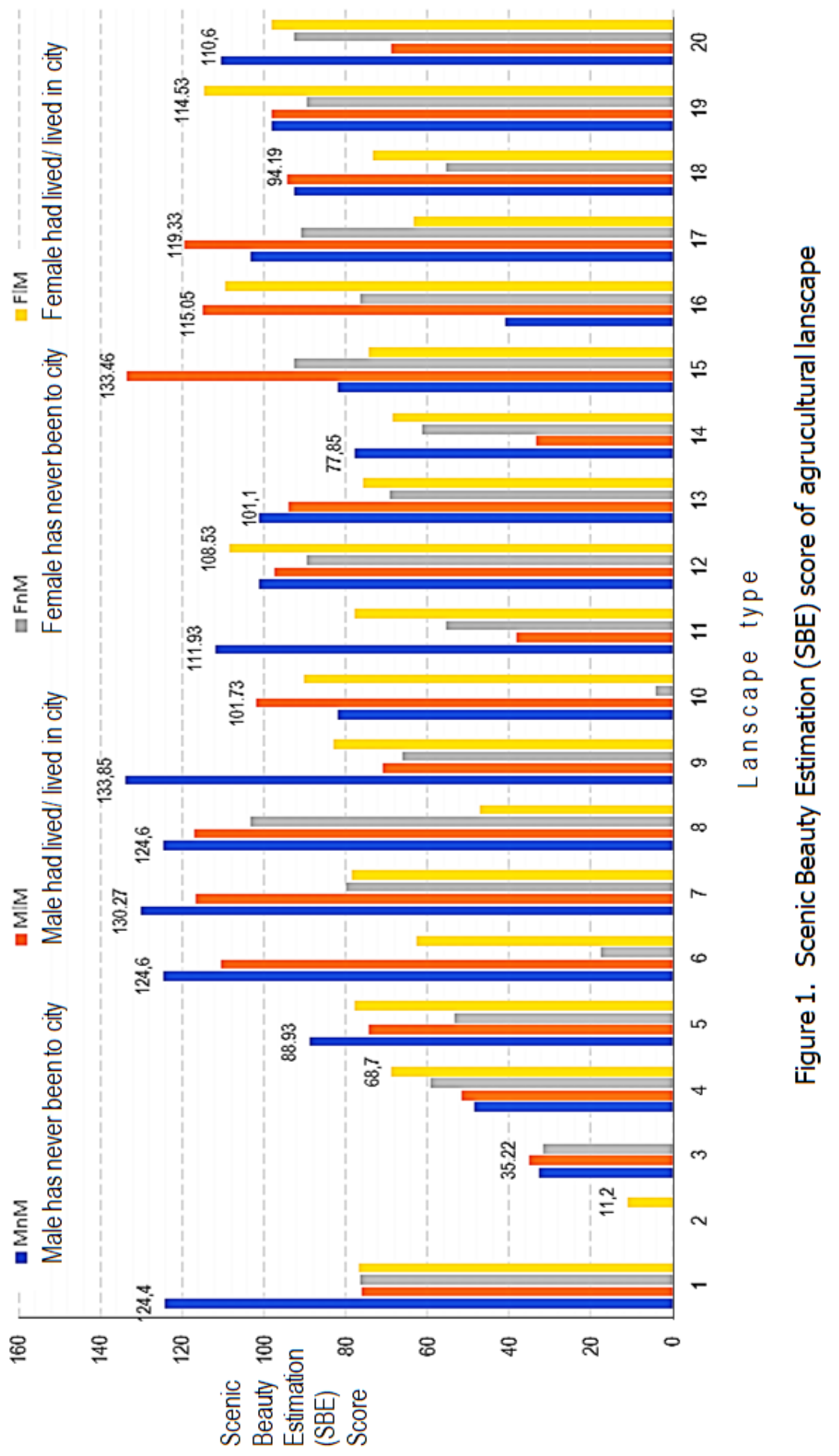


The diversity of perceptions indicates that there are differences in visual perceptions of each group. This analysis produces zoning of visual quality that can support visitors' activities in enjoying the beauty and comfort of the object attraction (Budiyono \& Soelistyari, 2016). It is the most crucial factor in enhancing the overall scenic beauty (Peng \& Han, 2018), such as the urban agricultural landscape, especially since the pandemic, the community's social activities have been more limited because of the recommendation to stay at home (Marroquín et al., 2020).

Table 3 shows an assessment of the visual preference of each respondent group. More than $50 \%$ of the male group, both who had been/lived and had never been to Makassar City, rated it in the high category. Meanwhile, only $50 \%$ of the women group rated it as high. However, this group gave a pretty good rating, bigger than the male group, which was $30 \%-40 \%$. Meanwhile, all respondents only gave a low rating of no more than $20 \%$. The positive perception is a form of satisfaction (Kinasih et al., 2020) that provides further urban agricultural development (Grebitus et al., 2020). Thus, agriculture in Makassar City has the opportunity to be developed as an agropolitan by paying attention to other macro planning (Nugroho et al., 2018), especially the tightening of community activities outside the region during a pandemic.

At the beginning of its development, some Makassar people associated green space with green colours in their environment. Consequently, in some alleys, they painted walls, fences, and roads green.

Apart from being a means of early education for children (Chenarides et al., 2021; Khan et al., 2020) during distance learning activities, encouraging women's participation (Azunre et al., 2019; Khan et al., 2020), and creating biodiversity (Galimberti et al., $\underline{2020})$, this green space effort can realize sustainable urban development (Adidja et al., 2019; Ibrahim \& Salim, 2020; Khan et al., 2020; Li et al., 2020b; Yusoff et $a_{.}$, 2017). It was different from before the pandemic, where urban agriculture was dominated by working family and a larger number of household (Chenarides et al., 2021). In Montreal, urban Canadian agriculture is still dominated by well-educated and high-income family groups (Bellemare \& Dusoruth, 2020).
The low category assessment in the 2nd landscape was cassava field in Sudiang Village, Biringkanaya District, and the 3rd landscape was chili fields owned by farmers in Barombong Village, Tamalate District (Figure 2). This low rating was because the two landscapes appeared to be dry and only had one plant type. Besides, the green colour seems to dominate the landscape so that it looks monotonous (Ilhami \& Gunawan, 2011). The middle categories were being given to a vacant land, namely the 4th landscape on land managed by the Az-Zahrah Women Farmers Group, Kapasa Raya Village, Biringkanaya District, and the 14th landscape on land planted with mustard greens and water spinach in Parang Tambung Village, Tamalate District. This assessment was because the cultivated plants were still in uniform colour, not much different from the low category landscape, but several types of plants had been cultivated. The high category was given to three landscapes. The first was the 7th landscape in the form of land on the Tallo River banks, which is managed by the Citra Women Farmers Group of Tello Baru Village, Panakukang District. The second was the 12th landscape is on empty land managed by the Selasih Women Farmer Group, Bangkala Village, Manggala District, and the last one was the 19th landscape, a vegetable plant verticulture planting technique in Barombong Village, Tamalate District. The four groups of respondents evaluated the three landscapes with high ratings due to the diversity of colours and types of plants and verticultural hydroponic cultivation techniques (Goodman \& Minner, 2019; Lal, 2020; Martin \& Molin, 2019) suitable for the increasingly narrow land in urban areas (ㄴi et al., 2020b; Nguyen et al., 2016) and the limited availability of clean water (Molden et al., 2010; Saccon, 2018).

Landscapes can give the impression of a large space and provide many alternative recreational activities that visitors can do, e.g. sightseeing or having picnic (Hidayat, 2009) in urban areas because landscape aesthetic indicators can be expressed as estimates of unique scenic beauty or well-being estimates (Fanariotu \& Skuras, 2004). Therefore, landscape management can also be given a special focus on suburban areas as residential developments that can develop rapidly (Molnárová et al., 2017). 
Low category

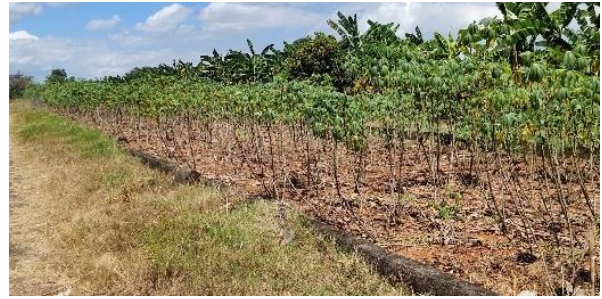

02 Cassava gardens

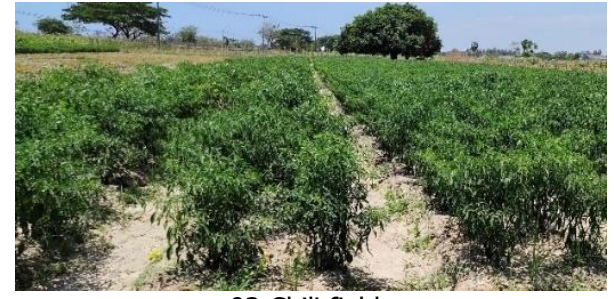

03 Chili fields

Middle category

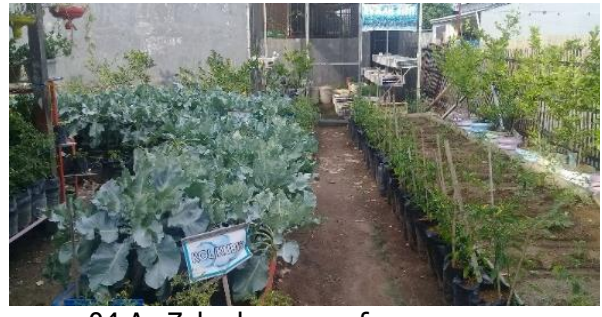

$04 \mathrm{Az}$-Zahrah women farmer group

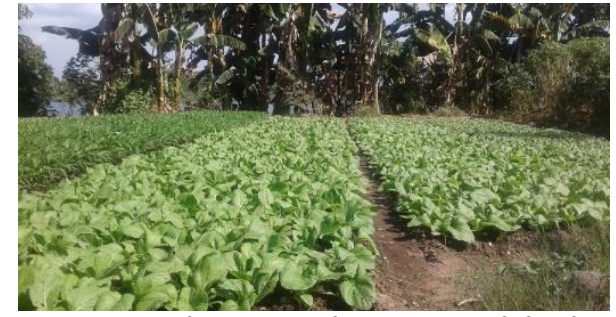

14 Mustard greens and water spinach land

High category

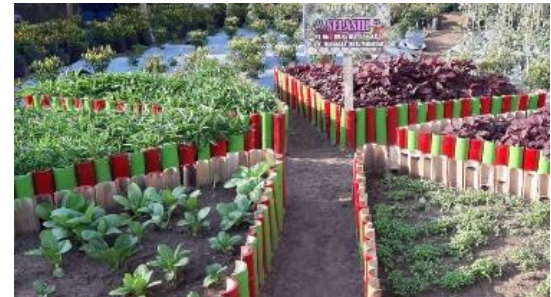

12 Selasih women farmer group

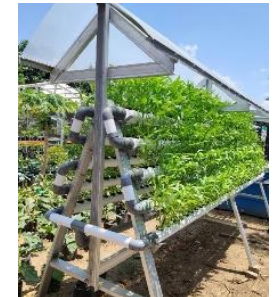

19 Verticultural hydroponic

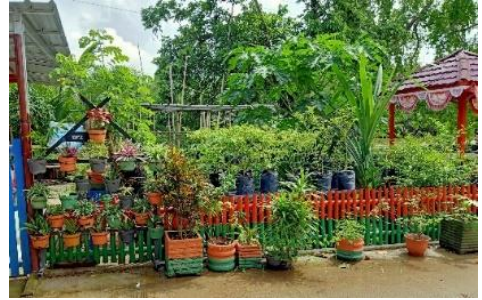

07 Citra women farmer group

Figure 2. Agricultural landscape by SBE category

Concerning these three categories, Budiyono \& Soelistyari (2016) stated that the assessment of preferences for landscapes has three levels: the most beautiful landscapes with a high level of preference, landscapes that are quite beautiful with a moderate level of preference, and the landscapes that are not beautiful with a low preference. For example, the preference assessment for the most beautiful agricultural landscape of Makassar City had a high preference, namely the 7th landscape, the 12th landscape, and the 19th landscape. The landscape is well-ordered, neat, and orderly with a harmonious combination of colours and plants and has artistic value. According to Hidayat (2009), beauty can emerge from visible lines, shapes, colours, and textures to provide inner satisfaction and five senses. Besides, the complexity of the shapes that also arise due to the planting pattern in a multilevel configuration provides a variety of views and unites with nature (Bell, 2004).

Table 4. Visual Perception Difference Test

\begin{tabular}{lrr}
\hline \multicolumn{1}{c}{ Item } & Male & \multicolumn{1}{c}{ Female } \\
\hline Mean & 79.85 & 71.60 \\
Variance & 1234.71 & 669.96 \\
Observations & 20 & 20 \\
\hline Pooled Variance & & 952.33 \\
df & & 38 \\
t-stat & & 0.84 \\
t Critical two-tail & & 2.02 \\
\hline
\end{tabular}

Visual perception based on sex differences showed no statistical difference between the two groups (Table 4). It is consistent with Table 2, where the male group evaluated a more excellent beautiful rating than 
the female group but graded a lower score of stunning beauty. These results can be used as urban agricultural development regardless the gender. This finding is in line with Shular et al. (2005), but not with Vanston \& Strother (2017), who argued that there are differences in the two's neurological abilities. Likewise, it is also in line with the findings of Bosley (1993); Jashari et al. (2018); Norman et al. (2018). Therefore, visual perception analysis needs to pay attention to other factors (Jashari et al., 2016, 2018), such as age and education level.

\section{Research Implication}

Urban agriculture is multifunctional (Valley \& Wittman, 2019), but the aesthetic function of landscapes is preferred over other uses such as houses or other urban infrastructure buildings (Aubry et al., 2012). This is indicated by a high SBE score. Agriculture in Makassar City with a high SBE score is managed by a group of women farmers. We can not deny it because women have more leisure time than men to manage the farm. This farm can also be used as a means of recreation or just a hobby that can reduce stress, even reduce gender inequality (Khan et al., 2020). The most cultivated agricultural products were horticulture with diverse colours and sizes. Urban agricultural development can empower women (Adidja et al., 2019; Khan et al., 2020), both in the production and marketing of products independently (Mulyani et al., 2019), as well as become a learning tool for children while doing distance-learning during the pandemic.

Then, the high visual perception of respondents, both who had been/lived in Makassar and who had never been to Makassar, shows the agricultural landscape's beauty level in Makassar. This assessment did not differentiate the results from male and female respondents. This provides opportunities for the development of Makassar as a sustainable city (Ibrahim \& Salim, 2020; Li et al., 2020b; Yusoff et al., 2017) through agropolitan development. It is expected to increase the income of the community, especially that of the middle to the lower class (Zezza \& Tasciotti, 2010). Likewise, with the success of urban agriculture and a positive perception (Grebitus et al., 2020; Yusoff et al., 2017) from the community influenced by age, gender, education level, and household size, people's interest in urban farming will increase (Admire, 2014; Ngahdiman et al., 2017). Of course, it is still important to pay attention to the macro-condition of Makassar
(Nugroho et al., 2018) and good urban management (Galimberti et al., 2020).

Therefore, through its extension workers, the government can provide resources and motivation for the community to like gardening starting from the yard, especially for people constrained by time and resources (Chenarides et al., 2021), besides maintaining the remaining agricultural land. Meanwhile, millennials can develop urban agriculture with more modern technology, such as hydroponics and verticulture techniques (Lal, 2020; Martin \& Molin, 2019), so that the stereotypes around farming such as being messy and dirty can be reduced. Thus, it is hoped that fresh (DiDomenica \& Gordon, 2016; Grebitus et al., 2020), healthy, and nutritious local food (Benis \& Ferrão, 2018; Ibrahim \& Salim, 2020) will be available during the pandemic and after the pandemic.

\section{CONCLUSION AND SUGGESTION}

The assessment of preferences for the most beautiful agricultural landscape of Makassar City has a high level of preference, namely on land planted with various plants and hydroponic cultivation techniques verticulture with the SBE score of 108.53, 114.53, and 130.27. A reasonably beautiful landscape has a moderate level of preference in the form of land that is only planted with two types of plants which is shown the SBE score of 68.7 and 77.85 so that the SBE value is in the medium category. While the landscape is not beautiful and has a low preference, there are gardens and rice fields that look arid and untidy with the SBE score of 11.2 and 35.22. Furthermore, the highest SBE score (133.85) as a potential attraction that men can develop is given by men compared to women.

The potential resources of urban agricultural landscapes must receive attention to be developed as an agropolitan by way of more neat, regular, and clean arrangement, so that they have high artistic value without differentiating gender. This beauty will provide comfort to visitors who come for leisure, both from inside and outside Makassar City. Thus, the limited land in urban areas does not preclude the opportunity to develop aesthetic agriculture regardless of age or gender.

Thus, it is hoped that the government will provide resources and support to households to develop urban agriculture and maintain the remaining agricultural land. Likewise, the millennials can contribute through 
more modern agricultural development. That way, we can reach food security, increase income, and city sustainability.

\section{ACKNOWLEDGMENT}

The authors want to thank the Makassar City Agriculture Office, the extension agents, farmer groups, and women farmers who have helped the research activities running well.

\section{REFERENCES}

Adidja, M. W., Mwine, J., Majaliwa, J. G. M., \& Ssekandi, J. (2019). The contribution of agroecology as a solution to hunger in the world: A review. Asian Journal of Agricultural Extension, Economics \& Sociology, 33(2), 1-22. https://doi.org/10.9734/ajaees/2019/v33i230170

Admire, J. (2014). Synergies between urban agriculture and urban household food security in Gweru City, Zimbabwe. Journal of Development and Agricultural Economics, 6(2), 59-66. https://doi.org/10.5897/JDAE2013.0506

Aubry, C., Ramamonjisoa, J., Dabat, M.-H., Rakotoarisoa, J., Rakotondraibe, J., \& Rabeharisoa, L. (2012). Urban agriculture and land use in cities: An approach with the multifunctionality and sustainability concepts in the case of Antananarivo (Madagascar). Land Use Policy, 29(2), 429-439. https://doi.org/10.1016/j.landusepol.2011.08.009

Azunre, G. A., Amponsah, O., Peprah, C., Takyi, S. A. \& Braimah, I. (2019). A review of the role of urban agriculture in the sustainable city discourse. Cities, 93, https://doi.org/10.1016/j.cities.2019.04.006

Bell, S. (2004). Elements of Visual Design in the Landscape (2nd ed.). Spon Press. Retrieved from https://pdf-drive.com/pdf/Simon20Bell2020Elements20of20Visual20Design20in20the20Lan dscape-Spon20Press2028200429.pdf

Bellemare, M. F., \& Dusoruth, V. (2020). Who participates in urban agriculture? An empirical analysis. Applied Economic Perspectives and Policy, 43, 430-442. https://doi.org/10.1002/aepp.13072

Benis, K., \& Ferrão, P. (2018). Commercial farming within the urban built environment - Taking stock of an evolving field in northern countries. Global Food Security, 17, 30-37. https://doi.org/10.1016/j.gfs.2018.03.005
Bonsdorff, P. von. (2005). Agriculture, Aesthetic Appreciation and the Worlds of Nature. 3. Retrieved from http://hdl.handle.net/2027/ spo.7523862.0003.007

Bosley, D. S. (1993). A study of gender and its influence on visual design. Technical Communication, 40(3), 543-547. Retrieved from https://www.jstor.org/stable/43091043

Brady, E. (2006). The aesthetics of agricultural landscapes and the relationship between humans and nature. Ethics, Place \& Environment, 9(1), 119. https://doi.org/10.1080/13668790500518024

Budiyono, D., Nurisjah, S., \& Adrianto, L. (2013). Perencanaan lanskap kawasan wisata pesisir Lalong Kota Luwuk, Sulawesi Tengah. Jurnal Lanskap Indonesia, 5(2), 21-27. https://doi.org/10.29244/jli.2013.5.2.21-27

Budiyono, D., \& Soelistyari, H. T. (2016). Evaluasi kualitas visual lanskap wisata Pantai Balekambang di Desa Srigonco, Kabupaten Malang. Jurnal Lanskap Indonesia, 8(2), 80-90. https://doi.org/10.29244/jli.2016.8.2.81-90

Chenarides, L., Grebitus, C., Lusk, J. L., \& Printezis, I. (2021). Who practices urban agriculture? An empirical analysis of participation before and during the COVID-19 pandemic. Agribusiness, 37(11), https://doi.org/10.1002/agr.21675

Child, I. L. (1964). Observations on the meaning of some measures of esthetic sensitivity. The Journal of Psychology, 57(1), 49-64. https://doi.org/10.1080/00223980.1964.9916671

Daniel, T.C., \& Boster, R. S. (1976). Measuring Landscape Aesthetic: The Scenic Beauty Estimation Method. USDA Forest Service. Retrieved from https://www.fs.fed.us/rm/pubs_rm/rm_rp167.pdf

Daniel, Terry C. (2001). Whither scenic beauty? Visual landscape quality assessment in the 21st century. Landscape and Urban Planning, 54(1-4), 267-281. https://doi.org/10.1016/S0169-2046(01)00141-4

Dearden, P. (1984). Factors influencing landscape preferences: An empirical investigation. Landscape Planning, 11(4), 293-306. https://doi.org/10.1016/0304-3924(84)90026-1

DiDomenica, B., \& Gordon, M. (2016). Food policy: Urban farming as a supplemental food source. Journal of Social Change, 8(1). https://doi.org/10.5590/JOSC.2016.08.1.01

Fanariotu, I., \& Skuras, D. (2004). The contribution of scenic beauty indicators in estimating 
environmental welfare measures: A case study. Social Indicators Research, 65, 145-165. https://doi.org/10.1023/A:1025802610622

Frank, S., Fürst, C., Koschke, L., Witt, A., \& Makeschin, F. (2013). Assessment of landscape aestheticsValidation of a landscape metrics-based assessment by visual estimation of the scenic beauty. Ecological Indicators, 32, 222-231. https://doi.org/10.1016/j.ecolind.2013.03.026

Galimberti, A., Cena, H., Campone, L., Ferri, E., Dell'Agli, M., Sangiovanni, E., Belingheri, M., Riva, M. A., Casiraghi, M., \& Labra, M. (2020). Rethinking urban and food policies to improve citizens safety after COVID-19 pandemic. Frontiers in Nutrition, 7, 569542. https://doi.org/10.3389/fnut.2020.569542

Geng, D. (Christina), Innes, J., Wu, W., \& Wang, G. (2020). Impacts of COVID-19 pandemic on urban park visitation: a global analysis. Journal of Forestry Research, 32(2), 553-567. https://doi.org/10.1007/s11676-020-01249-w

Goodman, W., \& Minner, J. (2019). Will the urban agricultural revolution be vertical and soilless? A case study of controlled environment agriculture in New York City. Land Use Policy, 83, 160-173. https://doi.org/10.1016/j.landusepol.2018.12.038

Grebitus, C., Chenarides, L., Muenich, R., \& Mahalov, A. (2020). Consumers' perception of urban farming-An exploratory study. Frontiers in Sustainable Food Systems, 4 https://doi.org/10.3389/fsufs.2020.00079

Hartmann, J., Sutcliffe, A., \& Angeli, A. De. (2008). Towards a theory of user judgment of aesthetics and user interface quality. ACM Transactions on Computer-Human Interaction, 15(4), 1-30. https://doi.org/10.1145/1460355.1460357

Hedblom, M., Hedenås, H., Blicharska, M., Adler, S., Knez, I., Mikusiński, G., Svensson, J., Sandström, S., Sandström, P., \& Wardle, D. A. (2020). Landscape perception: linking physical monitoring data to perceived landscape properties. Landscape Research, 45(2), 179-192. https://doi.org/10.1080/01426397.2019.1611751

Hidayat, I. W. (2009). Uji scenic beauty estimation terhadap konfigurasi tegakan-tegakan vegetasi di Kebun Raya Bogor. Prosiding Seminar Nasional Sains MIPA Dan Aplikasinya, 49-54. https://doi.org/10.13140/2FRG.2.1.4679.0560

Hill, D., \& Daniel, T. C. (2007). Foundations for an ecological aesthetic: Can information alter landscape preferences? Society \& Natural
Resources, 21(1), 34-49. https://doi.org/10.1080/08941920701655700

Ibrahim, L., \& Salim, S. A. (2020). The framework of urban farming towards enhancing quality of life in Malaysia. International Journal of Supply Chain Management, 9(1), 520-526. Retrieved from http://www.ojs.excelingtech.co.uk/index.php/IJSC M/article/view/4315

Ilhami, W. T., \& Gunawan, A. (2011). Persepsi Dan preferensi warna dalam lanskap. Jurnal Lanskap Indonesia, 3(2), 73-79. Retrieved from https://journal.ipb.ac.id/index.php/jli/article/view/ $5760 / 4456$

Jacobsen, T. (2010). Beauty and the brain: culture, history and individual differences in aesthetic appreciation. Journal of Anatomy, 216(2), 184191. 7580.2009.01164.x https://doi.org/10.1111/j.1469-

Jashari, A. S., Brand, A., Roinishvili, M., Kunchulia, M. Sierro, G., Willemin, J., Chkonia, E., Iannantuoni, L., Pilz, K., Mohr, C., \& Herzog, M. (2016). Gender differences in visual perception. Journal of Vision, 16(12), 207. https://doi.org/10.1167/16.12.207

Jashari, A. S., Roinishvili, M., Grzeczkowski, L., Chkonia, E., Pilz, K., Mohr, C., Brand, A., Kunchulia, M., \& Herzog, M. H. (2018). Sex-related differences in vision are heterogeneous. Scientific Reports, 8(1), 7521. https://doi.org/10.1038/s41598-018-25298-8

Khan, M. M., Akram, M. T., Janke, R., Qadri, R. W. K., Al-Sadi, A. M., \& Farooque, A. A. (2020). Urban horticulture for food secure cities through and beyond COVID-19. Sustainability, 12(22), 9592. https://doi.org/10.3390/su12229592

Kinasih, R. S., Roessali, W., \& Prasetyo, E. (2020). Visitors' satisfaction and development strategy of agrotourism: evidence from Semarang, Indonesia. Journal of Socioeconomics and Development, 3(2), 101-114. https://doi.org/10.31328/jsed.v3i2.1450

Lal, R. (2020). Home gardening and urban agriculture for advancing food and nutritional security in response to the COVID-19 pandemic. Food Security, 12, 871-876. https://doi.org/10.1007/s12571-020-01058-3

Li, C., Shen, S., \& Ding, L. (2020a). Evaluation of the winter landscape of the plant community of urban park green spaces based on the scenic beauty esitimation method in Yangzhou, China. Plos One, 15(10), e0239849. https://doi.org/10.1371/journal.pone.0239849

Li, L., Li, X., Chong, C., Wang, C.-H., \& Wang, X. (2020b). A decision support framework for the 
design and operation of sustainable urban farming systems. Journal of Cleaner Production, 268, 121928.

https://doi.org/10.1016/j.jclepro.2020.121928

Li, S., Nadolnyak, D., \& Hartarska, V. (2019). Agricultural land conversion: Impacts of economic and natural risk factors in a coastal area. Land Use Policy, 80, 380-390. https://doi.org/10.1016/j.landusepol.2018.10.016

López-Martínez, F. (2017). Visual landscape preferences in Mediterranean areas and their socio-demographic influences. Ecological Engineering, 104, 205-215. https://doi.org/10.1016/j.ecoleng.2017.04.036

Lothian, A. (1999). Landscape and the philosophy of aesthetics: is landscape quality inherent in the landscape or in the eye of the beholder? Landscape and Urban Planning, 44(4), 177-198. https://doi.org/10.1016/S0169-2046(99)00019-5

Marroquín, B., Vine, V., \& Morgan, R. (2020). Mental health during the COVID-19 pandemic: Effects of stay-at-home policies, social distancing behavior, and social resources. Psychiatry Research, 293, 113419.

https://doi.org/10.1016/j.psychres.2020.113419

Martin, M., \& Molin, E. (2019). Environmental assessment of an urban vertical hydroponic farming system in Sweden. Sustainability, 11(15), 4124. https://doi.org/htthttps://doi.org/10.3390/ su11154124

Mo, L., Chen, J., \& Xie, Y. (2021). Assessment of landscape resource using the scenic beauty estimation method at compound ecological system. Environmental Science and Pollution Research, 28(5), 5892-5899. https://doi.org/10.1007/s11356-020-10978-8

Molden, D., Oweis, T., Steduto, P., Bindraban, P., Hanjra, M. A., \& Kijne, J. (2010). Improving agricultural water productivity: Between optimism and caution. Agricultural Water Management, 97(4), 528-535. https://doi.org/10.1016/j.agwat.2009.03.023

Molnárová, J. K., Skřivanová, Z., Kalivoda, O., \& Sklenička, P. (2017). Rural identity and landscape aesthetics in exurbia: Some issues to resolve from a Central European perspective. Moravian Geographical Reports, 25(1), 2-12. https://doi.org/10.1515/mgr-2017-0001

Mulyani, H. S., Agustin, H., \& Zulfan, I. (2019). Implementation of community empowerment communication in the need of environmental food security through the Program "Bandung Agri
Market." International Journal of Psychosocial Rehabilitation, 23(2), 289-297. https://doi.org/10.37200/IJPR/V23I2/PR190290

Ngahdiman, I., Terano, R., Mohamed, Z., \& Sharifuddin., J. (2017). Factors affecting urban dwellers to practice urban agriculture. International Journal of Advanced Research, 5(7), 1580-1587.

https://doi.org/10.21474/IJAR01/4872

Nguyen, T. H. T., Tran, V. T., Bui, Q. T., Man, Q. H., \& Walter, T. de V. (2016). Socio-economic effects of agricultural land conversion for urban development: Case study of Hanoi, Vietnam. Land Use Policy, 54, 583-592. https://doi.org/10.1016/j.landusepol.2016.02.032

Norman, J. F., Dowell, C. J., Higginbotham, A. J., Fedorka, N. W., \& Norman, H. F. (2018). Sex and age modulate the visual perception of distance. Attention, Perception, \& Psychophysics, 80(8), 2022-2032. https://doi.org/10.3758/s13414-0181542-7

Nugroho, I., Negara, P. D., \& Yuniar, H. R. (2018). the planning and the development of the ecotourism and tourism village in Indonesia: A policy review. Journal of Socioeconomics and Development, 1(1), 43-51. https://doi.org/10.31328/jsed.v1i1.532

Nurfaida, Arifin, H. S., Sitorus, S. R. P., \& Eriyatno, A. (2019). Assessing scenic beauty of culture-based landscapes in North Toraja Regency. IOP Conference Series: Earth and Environmental Science, 399, 012040. https://doi.org/10.1088/1755-1315/399/1/012040

Palmer, S. E., Schloss, K. B., \& Sammartino, J. (2013). Visual aesthetics and human preference. Annual Review of Psychology, 64(1), 77-107. https://doi.org/10.1146/annurev-psych-120710100504

Peng, S.-H., \& Han, K.-T. (2018). Assessment of aesthetic quality on soil and water conservation engineering using the scenic beauty estimation method. Water, 10(4), 407. https://doi.org/10.3390/w10040407

Redies, C. (2014). Beauty: Neglected, but alive and kicking. British Journal of Psychology, 105(4), 468470. https://doi.org/10.1111/bjop.12083

Saccon, P. (2018). Water for agriculture, irrigation management. Applied Soil Ecology, 123, 793-796. https://doi.org/10.1016/j.apsoil.2017.10.037

Shi, Y., Lv, D., \& He, J. (2020). Landscape evaluation of urban parks based on SBE and AHP: a case study of Kunming City. IOP Conference Series: 
Earth and Environmental Science, 580, 012016. https://doi.org/10.1088/1755-1315/580/1/012016

Shular, C. F., Arruda, J. E., Greenier, K. D., \& Pratt, M. (2005). Sex differences in visual perception using stereopsis. Psi Chi Journal Of Undergraduate Research, 10(4), 139-144. Retrieved from https://cdn.ymaws.com/www.psichi.org/resource/ resmgr/journal_2005/winter05_shular.pdf

Skřivanová, Z., Kalivoda, O., \& Sklenička, P. (2014). Driving factors for visual landscape preferences in protected landscape areas. Scientia Agriculturae Bohemica, 45(1), 36-43. https://doi.org/10.7160/sab.2014.450105

Sowińska-Świerkosz, B. N., \& Chmielewski, T. J. (2016). A new approach to the identification of Landscape Quality Objectives (LQOs) as a set of indicators. Journal of Environmental Management, 184, 596-608. https://doi.org/10.1016/j.jenvman.2016.10.016

Svobodova, K., Sklenicka, P., Molnarova, K., \& Vojar, J. (2014). Does the composition of landscape photographs affect visual preferences? The rule of the Golden Section and the position of the horizon. Journal of Environmental Psychology, 38, 143152. https://doi.org/10.1016/j.jenvp.2014.01.005

Valley, W., \& Wittman, H. (2019). Beyond feeding the city: The multifunctionality of urban farming in
Vancouver, BC. City, Culture and Society, 16, 3644. https://doi.org/10.1016/j.ccs.2018.03.004

Vanston, J. E., \& Strother, L. (2017). Sex differences in the human visual system. Journal of Neuroscience Research, 95(1-2), 617-625. https://doi.org/10.1002/jnr.23895

Wang, Z., Li, M., Zhang, X., \& Song, L. (2020). Modeling the scenic beauty of autumnal tree color at the landscape scale: A case study of Purple Mountain, Nanjing, China. Urban Forestry \& Urban Greening, 47, 126526. https://doi.org/10.1016/j.ufug.2019.126526

Xie, J., Luo, S., Furuya, K., \& Sun, D. (2020). Urban parks as green buffers during the COVID-19 pandemic. Sustainability, 12(17), 6751. https://doi.org/10.3390/su12176751

Yusoff, N. H., Mohd Hussain, M. R., \& Tukiman, I. (2017). Roles of community towards urban farming activities. Planning Malaysia Journal, 15(1).

https://doi.org/10.21837/pmjournal.v15.i6.243

Zezza, A., \& Tasciotti, L. (2010). Urban agriculture, poverty, and food security: Empirical evidence from a sample of developing countries. Food Policy, 35(4), 265-273. https://doi.org/10.1016/j.foodpol.2010.04.007 